\title{
Antiviral activity of salivary microRNAs for ophthalmic herpes zoster
}

\author{
M Kemal Irmak ${ }^{1 *}$, Uzeyir Erdem² and Ayhan Kubar $^{3}$
}

\author{
* Correspondence: mkirmak@gata. \\ edu.tr \\ ${ }^{1}$ High Council of Science, Gulhane \\ Military Medical Academy, Ankara, \\ Turkey \\ Full list of author information is \\ available at the end of the article
}

\begin{abstract}
Ophthalmic herpes zoster is a common ocular infection caused by the varicella-zoster virus (VZV). Viral mRNA transcripts play a major role in the replicative cycle of the virus and current antiviral agents have little effect in preventing and treating the complications. Therapeutic use of saliva for certain painful ocular diseases such as ophthalmic herpes zoster is a well-known public practice in our region. We thought that antiviral activity of saliva may stem from salivary microvesicles and we aimed to look for molecules with antiviral activity in these vesicles. As a possible candidate for antiviral activity, salivary microvesicles contain at least 20 microRNAs (miRNAs), small noncoding RNAs, which suppress the translation of target mRNAs. miRNAs not only participate in maintenance of normal cell functions, but are also involved in host-virus interactions and limit the replication of certain virus types. Thus, miRNA gene therapy by targeting mRNAs required for VZV survival may find a niche in the treatment of ophthalmic herpes zoster. But, how could salivary microvesicles reach into the corneal cells to demonstrate their antiviral activity. We suggest that human salivary microvesicles can be effective carriers of miRNA for corneal cells, because they contain a molecular machinery for vesicle trafficking and fusion allowing them to be endocytosed by target cells. After binding to the plasma membrane, microvesicles seem to enter into the corneal cells through the clathrin-mediated endocytosis. In the cytosol, human salivary miRNAs base-pair with specific viral mRNAs and inhibit their translation, thus limiting the replication of the virus.
\end{abstract}

\section{Ophthalmic herpes zoster}

Herpes zoster is a common infection caused by the varicella-zoster virus (VZV). Approximately $20 \%$ of the world's population suffers from herpes zoster at least once in a lifetime, with $10 \%$ to $20 \%$ having ophthalmic involvement (ophthalmic herpes zoster) limited mainly to the cornea [1,2]. Ophthalmic herpes zoster has a very variable course; some cases resolve without trace after a minimum of treatment, others become indolent with chronic cellular and lipid infiltration. These patients present with varying degrees of decreased vision, pain, and light sensitivity [3]. Unfortunately this tends to occur more in young people and therefore these lesions should be observed and treated carefully [4]. Viral DNA is mainly found in mononuclear cells, in keratocytes, and in epithelial cells of the cornea [5]. Antiviral agents have demonstrated some success in resolving early signs and symptoms, but they have little effect in preventing and treating late complications [2].

(c) 2012 Irmak et al.; licensee BioMed Central Ltd. This is an Open Access article distributed under the terms of the Creative Commons Attribution License (http://creativecommons.org/licenses/by/2.0), which permits unrestricted use, distribution, and reproduction in any medium, provided the original work is properly cited. 


\section{Replicative cycle of the varicella-zoster virus}

Extensive transcription mapping showed that VZV contains 78 different mRNA transcripts of $6.8 \mathrm{~kb}$ or less [6]. After the entry of VZV into the cells, early viral mRNA transcripts are produced in the nucleus, translated in the cytoplasm, and proteins they encode are transported back to the nucleus, where they facilitate viral DNA replication [7]. Thereafter, late viral mRNAs are transcribed, translated, and proteins they encode are transported back to the nucleus for assembly into nascent capsids. Newly replicated DNA is then packaged into capsids in the nucleus, enveloped in the cytosol and transported to the cytoplasmic membrane, where the virions are released [7].

\section{Salivary miRNAs as antiviral agents}

Therapeutic use of saliva for certain painful ocular diseases such as ophthalmic herpes zoster is a well-known public practice in our region. We thought that antiviral activity of saliva may stem from salivary microvesicles (see Ref. [8] for details of microvesicles) and we aimed to look for molecules with antiviral activity in these microvesicles. As a possible candidate for antiviral activity, salivary microvesicles contain at least $20 \mathrm{miR}$ NAs, small noncoding RNAs, which suppress the translation of target mRNAs [9]. List of the most highly expressed human microRNAs in salivary microvesicles are: hsa-let-7b, hsa-let-7c*, hsa-miR-128, hsa-miR-150*, hsa-miR-17, hsa-miR-1908, hsa-miR-212, hsa-miR-27b*, hsa-miR-29b, hsa-miR-29c, hsa-miR-335, hsa-miR-379*, hsa-miR-433, hsa-miR-454, hsa-miR-483-3p, hsa-miR-584, hsa-miR-621, hsa-miR-652, hsa-miR-760 and hsa-miR-888* [9]. More recently, it was shown that salivary microvesicles also contain GW182, which is required for miRNA function [10].

MicroRNAs (miRNAs) are short non-coding RNAs that bind to and repress complementary mRNA targets [11]. The human genome contains more than 500 miRNAs, and each miRNA can repress hundreds of genes by targeting specific regions in the mRNA transcripts [12].

An important feature of microRNAs is their remarkable stability and resistance to degradation, especially compared to mRNA [9]. Increasing evidence suggests that miRNAs not only participate in maintenance of normal cell functions, but are also involved in host-virus interactions and limit the replication of certain virus types [13-17]. Thus, miRNA molecules that alter the function of specific viral mRNA transcripts represent a new strategy for treating viral diseases [18], and miRNA gene therapy by targeting mRNAs required for VZV survival may find a niche in the treatment of ophthalmic herpes zoster.

Since virus genome-specific non-coding small RNAs were reported to serve as successful antiviral agents against a number of ocular viral infections [19-21], we suggest here that miRNAs from salivary microvesicles can be used as therapeutic agents for ophthalmic herpes zoster. The transfer of miRNAs to the infective cornea through the salivary microvesicles and their subsequent regulation could result in the amelioration of the clinical manifestations of this ocular disease. But, how could these microvesicles reach into the corneal cells to demonstrate their antiviral activity.

Topical delivery to the eye is the most convenient way of ocular miRNA delivery, since it offers a noninvasive, simple delivery strategy with large surface absorption area [22]. However, the implementation of this type of therapy is actually hampered by the 
lack of an efficient carrier [23,24]. Therefore, a safe and effective miRNA delivery system is needed for miRNA-based antiviral therapy to achieve significant benefits in clinical settings. We suggest here that human salivary microvesicles can be effective carriers of miRNA for corneal cells, because they contain a molecular machinery for vesicle trafficking and fusion allowing them to be endocytosed by target cells. Human salivary microvesicles contain about 500 different proteins, a significant portion of which is involved in endocytosis, vesicular trafficking and fusion [25]. Of these, clathrin and Rab proteins (Rab5) are implicated in the process of endocytosis and engaged in transport and fusion [26]. In particular, Rab5 mediates the capture and fusion of clathrin-coated vesicles with endosomal membranes [27]. Other proteins like heat shock protein 70 participate in membrane translocation and decoating [25]. In addition to proteins, human salivary microvesicles contain more than 500 mRNA transcripts which could be transferred to other cells, translated into proteins and modulate the gene expression at their new location [28].

\section{Mechanisms of the microvesicle endocytosis by corneal cells}

Membrane-bound compartments newly formed from the corneal cell surface normally enter the endosomal/lysosomal network, which is an inhospitable environment [29]. Viruses which are valuable models of cellular entry and intracellular trafficking pathways avoid lysosomal degradation, which is a dead end for many particles in a classic endocytic pathway. Entry of adenovirus into the corneal cells is emerging as a useful paradigm in the field. After adenovirus is internalized through clathrin-mediated endocytosis; it is entrapped in the endosomes [30]. Protein VI of the adenovirus causes membrane disintegration and allows adenovirus to escape the endosomes by forming pores [31-34]. In cytosol, heat shock protein 70 facilitates the disassembly of the coat protein from the virus (decoating of adenovirus) [35]. Similarly salivary microvesicles contain a molecular machinery for clathrin mediated endocytosis and are capable to decoat the microvesicular membrane by heat shock protein 70 [25]. Therefore, after cellular uptake, these microvesicles are able to harbor a mechanism that mimics that used by adenoviral particles to escape from the endosomal/lysosomal pathway and proceed to the cytosol.

\section{A scenario for the therapy of ophthalmic herpes zoster through microvesicu- lar miRNA of saliva}

After binding to the plasma membrane, microvesicles enter the corneal cells through the clathrin-mediated endocytosis. After penetration into the cell, microvesicles translocate Rab5 proteins to the outer surface of the vacuolar membrane by a syringe-like mechanism while moving toward the endosome [36]. These proteins help the microvesicles to pass from membrane to the endosome and vacuoles containing microvesicles fuse with endosome. In the endosome, some other proteins take role for the microvesicles to escape into the cytosol [37]. In cytosol, decoating of the microvesicular membrane occurs with the help of heat shock protein 70 and the released mRNA is translocated into the cytosol directly together with miRNA. In the cytosol, the linear copy of the microvesicular mRNA is translated into proteins by the cellular enzymes. In this way, about 500 transcripts representing the microvesicular transcriptome from 
saliva can be expressed in the corneal cells [28]. Human salivary microvesicles also express more than 20 different miRNAs with a potential to repress the viral mRNA transcripts directly [9]. These miRNAs base-pair with specific viral mRNAs and inhibit their translation, thus limiting the replication of the virus. Since a single miRNA can act to repress many complementary viral mRNAs, this method may allow saliva to be a useful tool in the treatment of the ophthalmic herpes zoster [38].

Competing interests

The authors declared that they have no competing interest.

\section{Acknowledgements}

This work is dedicated to Dear Ali whose painful ocular disease was treated by the saliva of his lovely Cousin.

\section{Author details}

${ }^{1}$ High Council of Science, Gulhane Military Medical Academy, Ankara, Turkey. ${ }^{2}$ Department of Ophtalmology, Gulhane Military Medical Academy, Ankara, Turkey. ${ }^{3}$ Department of Virology, Gulhane Military Medical Academy, Ankara, Turkey.

\section{Authors' contributions}

MKI proposed the concept of antiviral activity of salivary microRNAs for ocular diseases and reviewed the relevant literature. UE was primarily responsible for the consistency of ophthalmic herpes zoster with the hypothesis. AK investigated the entry of adenovirus into the corneal cells. All authors read and agreed the final manuscript.

Received: 18 April 2012 Accepted: 25 May 2012

Published: 7 June 2012

\section{References}

1. Pavan-Langston D: Herpes zoster antivirals and pain management. Ophthalmol 2008, 115:S13-S20

2. Karbassi M, Raizman MB, Schuman JS: Herpes zoster ophthalmicus. Surv Ophthalmol 1992, 36:395-410.

3. Shaikh S, Ta CN: Evaluation and management of herpes zoster ophthalmicus. Am Fam Physician 2002, 66:1723-1730.

4. Marsh RJ: Ophthalmic zoster. Br J Ophthalmol 1992, 76:244-245.

5. Wenkel H, Rummelt C, Rummelt V, Jahn G, Fleckenstein B, Naumann GO: Detection of varicella zoster virus DNA and viral antigen in human cornea after herpes zoster ophthalmicus. Cornea 1993, 12:131-317.

6. Reinhold WC, Straus SE, Ostrove JM: Directionality and further mapping of varicella zoster virus transcripts. Virus Res 1988, 9:249-261.

7. Cohen Jl, Straus SE, Arvin AM: Varicella-zoster virus. In Fields Virology. 5th edition. Edited by Knipe DM, Howley PM, Griffin DE, Lamb RA, Martin MA, Roizman B, Straus SE. Philadelphia: Lippincott Williams \& Wilkins; 2007:2773-2818.

8. Irmak MK, Oztas Y, Oztas E: RNA-based gene delivery system hidden in breast milk microvesicles. J Exp Integr Med 2012, 2:125-136.

9. Michael A, Bajracharya SD, Yuen PS, Zhou H, Star RA, Illei GG, Alevizos I: Exosomes from human saliva as a source of microRNA biomarkers. Oral Dis 2010, 16:34-38.

10. Ogawa Y, Miura Y, Harazono A, Kanai-Azuma M, Akimoto Y, Kawakami H, Yamaguchi T, Toda T, Endo T, Tsubuki M, Yanoshita R: Proteomic analysis of two types of exosomes in human whole saliva. Biol Pharm Bull 2011, 34:13-23.

11. Broderick JA, Zamore PD: MicroRNA therapeutics. Gene Ther 2011, 18:1104-1110.

12. Bartel DP: MicroRNAs: target recognition and regulatory functions. Cell 2009, 136:215-233.

13. Umbach $J$, Cullen BR: The role of RNAi and microRNAs in animal virus replication and antiviral immunity. Genes Dev 2009, 23:1151-1164

14. Lecellier $\mathrm{CH}$, Dunoyer $\mathrm{P}$, Arar K, Lehmann-Che J, Eyquem S, Himber C, Saïb A, Voinnet O: A cellular microRNA mediates antiviral defense in human cells. Science 2005, 308:557-560.

15. Triboulet R, Mari B, Lin YL, Chable-Bessia C, Bennasser Y, Lebrigand K, Cardinaud B, Maurin T, Barbry P, Baillat V, Reynes J, Corbeau P, Jeang KT, Benkirane M: Suppression of microRNA-silencing pathway by HIV-1 during virus replication. Science 2007, 315:1579-1582.

16. Yeung ML, Bennasser $Y$, Myers TG, Jiang G, Benkirane $M$, Jeang $K T$ : Changes in microRNA expression profiles in HIV-1-transfected human cells. Retrovirology 2005, 28:2-81.

17. Lagos D, Pollara G, Henderson S, Gratrix F, Fabani M, Milne RS, Gotch F, Boshoff C: miR-132 regulates antiviral innate immunity through suppression of the p300 transcriptional co-activator. Nat Cell Biol 2010, 12:513-519.

18. Zheng SQ, Li YX, Zhang Y, Li X, Tang H: MiR-101 regulates HSV-1 replication by targeting ATP5B. Antiviral Res 2011, 89:219-226.

19. Williams KA, Coster DJ: Gene therapy for diseases of the cornea - a review. Clin Experiment Ophthalmol 2010, 38:93-103.

20. Mohan RR, Tovey JC, Sharma A, Tandon A: Gene therapy in the Cornea: 2005-present. Prog Retin Eye Res 2011 , 31:43-64.

21. Jun EJ, Won MA, Ahn J, Ko A, Moon H, Tchah H, Kim YK, Lee H: An antiviral small-interfering RNA simultaneously effective against the most prevalent enteroviruses causing acute hemorrhagic conjunctivitis. Invest Ophthalmol Vis Sci 2011, 52:58-63. 
22. Tong YC, Chang SF, Liu CY, Kao WW, Huang CH, Liaw J: Eye drop delivery of nano-polymeric micelle formulated genes with cornea-specific promoters. J Gene Med 2007, 9:956-966.

23. Contreras-Ruiz L, de la Fuente M, Párraga JE, López-García A, Fernández I, Seijo B, Sánchez A, Calonge M, Diebold Y: Intracellular trafficking of hyaluronic acid-chitosan oligomer-based nanoparticles in cultured human ocular surface cells. Mol Vis 2011, 17:279-290.

24. Qaddoumi MG, Ueda H, Yang J, Davda J, Labhasetwar V, Lee VH: The characteristics and mechanisms of uptake of PLGA nanoparticles in rabbit conjunctival epithelial cell layers. Pharm Res 2004, 21:641-648.

25. Gonzalez-Begne M, Lu B, Han X, Hagen FK, Hand AR, Melvin JE, Yates JR: Proteomic analysis of human parotid gland exosomes by multidimensional protein identification technology (MudPIT). J Proteome Res 2009, 8:1304-1314

26. Gorvel JP, Chavrier P, Zerial M, Gruenberg J: rab5 controls early endosome fusion in vitro. Cell 1991, 64:915-925

27. Bucci C, Parton RG, Mather $I H$, Stunnenberg $H$, Simons $K$, Hoflack B, Zerial M: The small GTPase rab5 functions as a regulatory factor in the early endocytic pathway. Cell 1992, 70:715-728.

28. Sharma S, Rasool HI, Palanisamy V, Mathisen C, Schmidt M, Wong DT, Gimzewski JK: Structural-mechanical characterization of nanoparticle exosomes in human saliva, using correlative AFM, FESEM, and force spectroscopy. ACS Nano 2010, 4:1921-1926.

29. Ziello JE, Huang Y, Jovin IS: Cellular endocytosis and gene delivery. Mol Med 2010, 16:222-229.

30. Chailertvanitkul VA, Pouton CW: Adenovirus: a blueprint for non-viral gene delivery. Curr Opin Biotechnol 2010, 21:627-632.

31. Rux JJ, Burnett RM: Adenovirus structure. Hum Gene Ther 2004, 15:1167-1176.

32. Medina-Kauwe LK: Endocytosis of adenovirus and adenovirus capsid proteins. Ad Drug Deliv Rev 2003, 55:1485-1496

33. Meier O, Boucke K, Hammer SV, Keller S, Stidwill RP, Hemmi S, Greber UF: Adenovirus triggers macropinocytosis and endosomal leakage together with its clathrin-mediated uptake. J Cell Biol 2002, 158:1119-1131.

34. Prchla E, Plank C, Wagner E, Blaas D, Fuchs R: Virus-mediated release of endosomal content in vitro: different behaviour of adenovirus and rhinovirus serotype 2. J Cell Biol 1995, 131:111-123.

35. Meier O, Greber UF: Adenovirus endocytosis. J Gene Med 2004, 6:S152-S163.

36. De Buck E, Anne J, Lammertyn E: The role of protein secretion systems in the virulence of the intracellular pathogen Legionella pneumophila. Microbiology 2007, 153:3948-3953.

37. Gastaldelli M, Imelli N, Boucke K, Amstutz B, Meier O, Greber UF: Infectious adenovirus type 2 transport through early but not late endosomes. Traffic 2008, 9:2265-2278

38. Guran S: Proceeded diagnosis and therapy in eye diseases under the light of developments in molecular biology and genetics. Gulhane Med J 2011, 53:74-76.

doi:10.1186/1742-4682-9-21

Cite this article as: Irmak et al: Antiviral activity of salivary microRNAs for ophthalmic herpes zoster. Theoretical Biology and Medical Modelling 2012 9:21.

\section{Submit your next manuscript to BioMed Central and take full advantage of:}

- Convenient online submission

- Thorough peer review

- No space constraints or color figure charges

- Immediate publication on acceptance

- Inclusion in PubMed, CAS, Scopus and Google Scholar

- Research which is freely available for redistribution

Submit your manuscript at www.biomedcentral.com/submit 